\title{
DESIGN, CONSTRUCTION AND PERFORMANCE EVALUATION OF A SOLAR DRYING UNIT OF BASIL LEAVES
}

\section{A. T. Imbabi*, \\ H. S. Abdel-Galil ${ }^{* *}$ and T. KH. Abdel-Kader ${ }^{* * *}$}

ABSTRACT

Two similar solar drying units were designed, constructed and evaluated for drying basil leaves (Ocimum basilicum L.) as a medicinal and aromatic plant at initial moisture content of $590.73 \%$ (d.b) or $85.52 \%$ (w.b) under Fayoum conditions by using heated air. Each drying unit consists of a flat-plate solar collector, which oriented and tilted with an optimum tilt angle and attached with drying chamber. The drying experiments were carried out to examine the effect of basil leaves thicknesses $(2,4$ and $6 \mathrm{~cm})$ and airflow rate $\left(0.015\right.$ and $\left.0.025 \mathrm{~m}^{3} . \mathrm{sec}^{-1}\right)$ on the basil leaves drying rate. The obtained results indicated that the daily average total solar radiation flux incident on the tilted solar collector surface (29.30 MJ. $\left.\mathrm{m}^{-2} . \mathrm{day}^{-1}\right)$ was greater than that incident on the horizontal surface $\left(24.30 \mathrm{MJ} . \mathrm{m}^{-2} . d a y^{-1}\right)$ by $24.58 \%$. The output higher air temperatures were obtained at the lower airflow rate whereas; the energy gained to the air from the solar collector was relatively higher at the higher airflow rate as compared with the lower airflow rate. Consequently, the solar collector with the higher airflow rate increased the overall thermal efficiency by $5.46 \%$ as compared to the lower airflow rate. The moisture content of dried basil leaves was strongly affected by the basil leaves thickness and the airflow rate. The final moisture content of dried basil leaves ranged from (11.52\% to $14.58 \%$ d.b) depending on the drying temperature cycle. Very small changes were observed in the colour and shape of heated-air dried basil leaves as compared to that dried at direct sun rays. The essential oil contents of dried basil leaves were slightly higher for the drying unit with the higher airflow rate as compared with the corresponding values obtained from the drying unit with the lower airflow at all basil leaves thicknesses.

\footnotetext{
* ** Prof., and Assist. Prof. ; Agric. Eng.; Fac. of Agric. Fayoum Univ., Egypt. ** Post Graduate Student of Agric. Eng.; Fac. of Ag. Fayoum Univ., Egypt.
} 
While on Contrast, total chlorophylls contents were slightly higher for the drying unit with the lower airflow rate as compared with the corresponding values obtained from the drying unit with the higher airflow at all basil leaves thicknesses. Effect of the individual variables (airflow rate, basil leaves thickness, moisture removed, and their interactions) on the drying rate was statistically analyzed. Under the conditions of this study, the optimum depth to dry basil leaves by using heated air is $4 \mathrm{~cm}$.

\section{INTRODUCTION}

7 medicinal and aromatic plants are cultivated in all over the world especially in Egypt for both local consumption and export.

sweet basil is one of the most important aromatic plants cultivated in Fayoum Governorate (especially at Abchway district), Egypt. Schenkel et al. (2003) indicated that the use of medicinal plants is part of a competitive market, which includes pharmaceuticals, food, cosmetics, and perfumery markets. In pharmaceuticals, plant extracts are especially relevant due to the use of their active substances for medicine development and as source to obtain adjuvant. CAGMC (2003) reported that the cultivated area of medicinal and aromatic plants in Egypt is about 1091 feddans, producing about 1951 ton/year from green plants and 29.26 ton essential oil. Many farmers in Egypt still using natural sun and wind to dry aromatic plants, but low quality and high losses occur because during this drying method, the aromatic plants are not protected from dust, rain, birds, and insects. Bowles (2004) mentioned that in all regions of the world, the history of peoples shows that medicinal and aromatic plants have always occupied an important place in medicine, the composition of perfumes, food and in cooking. Bozin et al. (2006) indicated that recently, there has been much research into the health benefits conferred by the essential oils found in basil. Scientific studies in vitro have established that compounds in basil oil have potent antioxidant, antiviral, and antimicrobial properties, and potential for use in treating cancer. Tohti et al. (2006) reported that basil has been shown to decrease the occurrence of platelet aggregation and experimental thrombus in mice. It is traditionally used for supplementary treatment of stress, asthma and diabetes in India. 
Pierce and Thompson (1980) indicated that the airflow rate is the most important factor in the design and operation of low temperature drying systems regardless of whether natural air or heated air is used. Muhlbauer, (1986) mentioned that sun drying is still the most common method used to preserve agricultural products in most tropical and subtropical countries. However, being unprotected from rain, wind borne dirt, dust, and infestation by insects, rodents and other animals. Sun dried product may be seriously degraded to the extent that sometimes it becomes inedible, and the resulted loss of food quality in the dried product may have adverse economic effects on domestic and international markets. So that, the introduction of solar dryers in developing countries can reduce crop losses and improve the quality of dried product significantly compared with traditional drying method. PaTil and Ward (1989) classified solar drying process into three modes on the basis of drying air temperatures namely: (a) natural air drying, (b) supplemental heated air drying and (c) heated air drying. Hazra et al. (1990) indicated that drying medicinal and aromatic plants in direct sunlight produced 24\% less vapor than required during distillation. Okos $\boldsymbol{e t}$ al. (1992) indicated that the main aim of drying products is to allow longer periods of storage, minimize packaging requirements and reduce shipping weight.

Hassanain (2004) dried medicinal plants (henna, rosemary and marjoram) using unglazed transpired solar dryer. He indicated that the average efficiency of the solar dryer used was varied due to the type of the medicinal plants and the weather conditions of the location. AbdelGalil and Tarhuni (2005) used solar dryer to dry peppermint (Mentha Peperita) under Tripoli conditions, Libya by using heated air. They indicated that increasing the airflow rate and the peppermint depth, reduced the drying time by 15 to $20 \%$. The final moisture content was 6.2 $\%$ (d. b.) and $6.8 \%$ (d. b.) at the airflow rates of 0.015 and $0.025 \mathrm{~m}^{3} / \mathrm{s}$, respectively. Oztekin and Martinov (2007) indicated that drying of aromatic and medicinal plants must meet the following requirements: (1) Moisture content has to be brought down to be at an equilibrium level that is defined for certain relative air humidity and temperature. This is defined as storage condition by standards; (2) minimum quality reduction in terms of active ingredients, color, flavor and aroma; and (3) microbial count must be below the prescribed limits. Arafa (2007) indicated that 
the drying method of sweet basil leaves gave the average drying rates of $43.4 \%, 47.4 \%$ and $59.4 \%$ (d.b/hr) for drying periods of 12, 11 and $9 \mathrm{hr}$. with an average drying air temperatures of 35,40 and $45^{\circ} \mathrm{C}$ ) respectively. The total chlorophyll of 84,64 and $48 \mathrm{mg} / 100$ grams of the samples were also obtained, respectively. The volatile oil percentages for the three different drying air temperatures were 88.2, 84.6 and $78.9 \%$, respectively. Kadam et al. (2011) investigated the effect of different drying conditions on kinetics of basil leaves, the laboratory models of tunnel and tray dryers were employed and air temperatures of 55, 60 and $65^{\circ} \mathrm{C}$ were considered for the drying. Drying of basil leaves prominently occurred in falling rate period and it was found that basil leaves dried faster in tray dryer. The effective moisture diffusivity $\left(D_{\text {eff }}\right)$ of basil leaves increased with the increase in drying air temperature. The $D_{\text {eff }}$ values were higher for tray dryer than those dried in the tunnel dryer. Effective moisture diffusivity of basil

leaves ranged from $2.65 \times 10^{-10}$ to $5.69 \times 10^{-10} \mathrm{~m}^{2} / \mathrm{s}$. Shahi et al. (2014) investigate the influence of different drying methods (Sun, Solar and vacuum drying) with different drying air temperature $\left(55,60\right.$ and $\left.65^{\circ} \mathrm{C}\right)$ on activation energy kinetics of basil leaves. They concluded that the increase in drying air temperature decreased the drying time in both the drying methods while, basil leaves dried faster in solar dryer.

Yousif et al. (1999) used conventional hot air or the vacuum-microwave dryers to study the effect of the basil leaves drying method on the relative abundance of major flavor volatiles, rehydration rate, color, and structural integrity of the plant. Vacuum microwave dehydrated basil yielded approximately 2.5 times the linalool and 1.5 times the methylchavicol of the air-dried samples. Ertekin and Yaldiz (2004) reported that the drying process should be undertaken in closed equipment to improve the quality of the final product. In an another study, dried basil leaves were evaluated for retention of some volatile compounds using both conventional hot air (50, 60 and $70^{\circ} \mathrm{C}$ ) and low-pressure superheated steam (LPSS) dryers. The LPSS drying proved to be better in terms of the aroma compounds content. Özcan et al. (2005) reported that basil can be oven dried (at 50 ${ }^{\circ} \mathrm{C}$ ) to $17.31 \%$ moisture content after $15 \mathrm{~h}$ and can be sun dried (temperatures between 30 and $35^{\circ} \mathrm{C}$ ) to $23.79 \%$ moisture content after 28 h. They also, indicated that the mineral content of oven dried herbs was 
higher than sun dried herbs. $\mathrm{K}, \mathrm{Ca}, \mathrm{S}, \mathrm{Mg}, \mathrm{Fe}$ and $\mathrm{Al}$ contents were determined as main minerals in both oven and sun dried basil. AbdelGalil and El-Nakib (2008) investigated the effect of two different natural convection solar drying systems on the quality of two species of peppermint (mentha pepperita and mentha vridis). They reported that oven drying method gave the lowest essential oil and chlorophylls A and B contents as compared with the two solar drying methods. Also, the essential oil content and chlorophylls A and B contents were slightly higher for the direct dryer as compared with that of the indirect dryer. Banout et al. (2010) studied two solar drying methods (direct cabinet solar dryer and indirect cabinet solar dryer) on the chemical composition of aerial parts of sacha culantro (Eryngium foetidum). The authors concluded that when comparing both solar drying methods, the indirect method was found as more suitable for drying E. foetidum since the dried product resembled the fresh herb more closely in its chemical composition and had better appearance. Many other authors found variations in the chemical composition of essential oil of different medicinal plants according to the drying air temperature (Khangholil and Rezaeinodehi, 2008; Baydar and Erbas, 2009; Sellami et al., 2011).

The specific objectives of this study are to:

1. Design and construct a solar drying unit able to dry aromatic and medicinal plants and evaluate its thermal performance.

2. Investigate the factors affecting the drying process of basil leaves.

3. Determine most important chemical characteristics of dried basil leaves.

\section{MATERIALS AND METHODS}

\section{A. The Solar dryer set-up:}

Two similar solar drying units were developed and constructed for drying sweet basil leaves in Fayoum Faculty of Agriculture, Fayoum University, Egypt on August, 2014 by using heated air. The latitude and longitude angles for the specific location are $29.18^{\circ} \mathrm{N}$ and $30.3^{\circ}$, respectively. Each drying unit consists of a solar collector attached with drying chamber. The only difference between the two drying units was in the air suction fan of each solar collector, whereas, the drying chamber is similar for both units. Fig. (1) shows a photograph of the experimental set up. A 
schematic representation for the solar drying unit of the experimental setup is shown at (Fig.2), and the following are details of the components:

1. Flat-plate solar collector: A single flat-plate solar collector with airflow over the absorber was made of rectangular wooden box. It has a surface area of $2.0 \mathrm{~m}^{2}$ (2.0 m long, $1.0 \mathrm{~m}$ wide and $0.15 \mathrm{~m}$ thickness). The solar collector was painted from inside and outside surfaces using matt black paint. Galvanized flat metal plate painted matt black which having absorpitivity and emissivity of 0.95 and 0.87 respectively, was used as an absorber plate to absorb the maximum amount of solar energy. Transparent cover of glass sheet $(2.7 \mathrm{~mm}$ thickness) is placed $7 \mathrm{~cm}$ on the upper side of absorber plate to reduce thermal losses. A fiber glass wool $\left(24 \mathrm{~kg} . \mathrm{m}^{-3}\right)$ with thickness of $0.025 \mathrm{~m}$ and a thermal conductivity of $0.045 \mathrm{~W} . \mathrm{m}^{-1} .{ }^{\circ} \mathrm{C}^{-1}$ was used to insulate the sides and bottom of the solar collector. A suction fan with control valve at its outlet $(150 \mathrm{~mm}$ diameter, model No.OC-15R, 220 Volt, 50 Hertz, Ocarina made) was attached in the front entrance of the solar collector to introduce the ambient air $\left(\mathrm{T}_{\mathrm{a}}\right)$ to it for heating and, then, passes through the drying chamber. The suction fan was lifted up from the earth's surface, to prevent the air entering the solar collector from pollution, and to avoid the air from mixing with dust. Three openings were made at the other end of the solar collector to introduce the heated air to the drying chamber. The solar collector was orientated to face south direction and tilted with an optimum tilt angle.

2. Drying chamber: The drying chamber was a rectangular box $(1.0 \mathrm{~m}$ length, $1.0 \mathrm{~m}$ width and $0.8 \mathrm{~m}$ depth) constructed of wooden. In the middle of the drying chamber, wooden supports were fixed at two parallel sides of it for placing the drying tray. The drying tray was made of an iron frame with $0.2 \mathrm{~cm}$ mesh stainless steel wire screen to permit drying air passing throughout it. The drying tray was divided into three sections: the first section of the $2-\mathrm{cm}$, the second section of the $4-\mathrm{cm}$ and the third section of the 6-cm sweet basil leaves thickness layers. The drying tray was inserted into (or removed from) the drying chamber through a hinged door, which was tightly sealed during the drying process. The inlet and outlet ducts $(0.5 \times 0.5 \mathrm{~m})$ with $0.15 \mathrm{~m}$ depth were attached to the drying chamber to allow uniform air distribution inside it and delivers the exhaust air to the atmosphere. Two Orifice plates with $2.0 \mathrm{~cm}$ openings were used to measure the airflow rate. The exhaust air leaves the drying 
through the chimney, which was protected by a cover to prevent the ambient air from entering the drying chamber when the drying process was off. The drying chamber was painted from outside surfaces using matt black paint to minimize the heat losses to the ambient atmosphere, especially during the drying process. The drying chamber was mounted on a wooden stand which was elevated by $1.5 \mathrm{~m}$ from the ground.

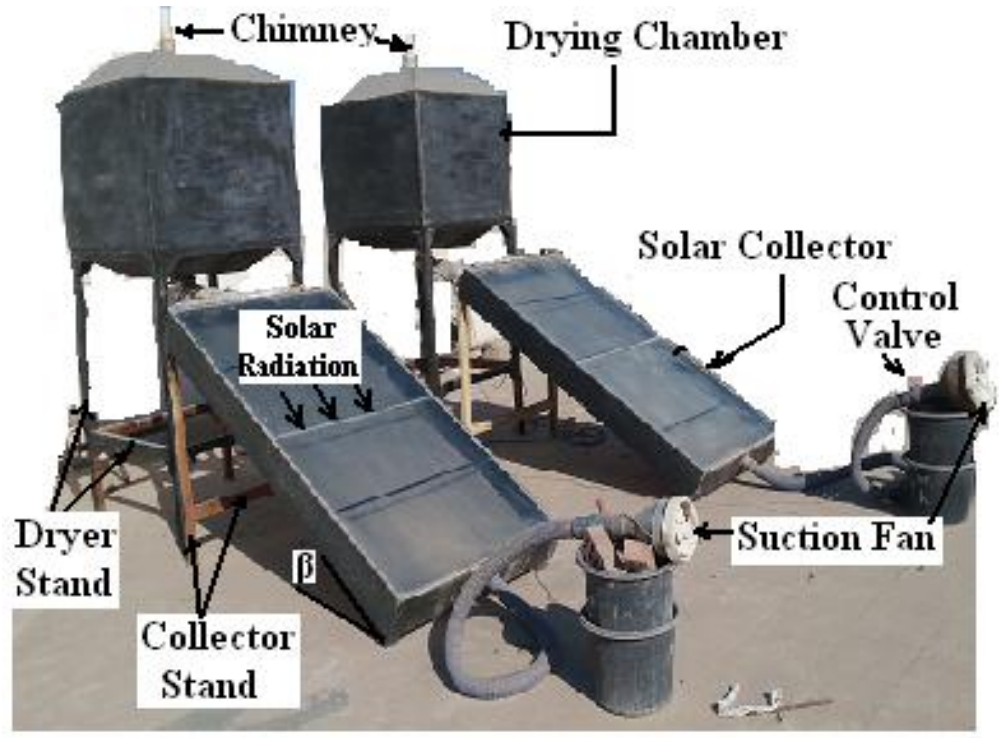

Fig. (1): A Photograph Showing the Experimental Set Up.

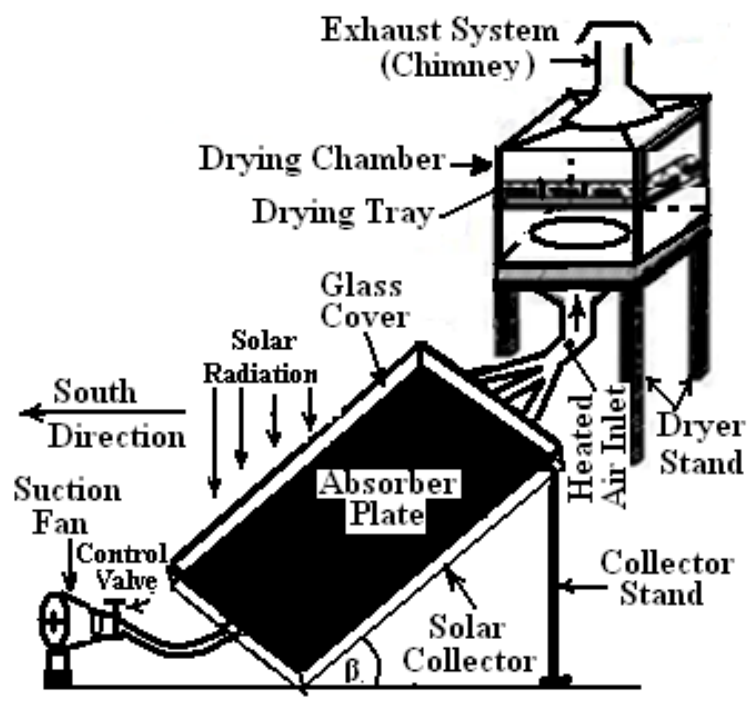

Fig. (2): Schematic Representatiomn of the Experim, ental Set Up 


\section{B. Some physical properties of sweet basil:}

Sweet basil is a common name for the culinary herb "Ocimum basilicum" of the family Lamiaceae. Sweet basil leaves may taste somewhat like anise, with a strong, pungent, often sweet smell. There are many varieties of "Ocimum basilicum", as well as several related species or species hybrids also called basil. The type used in Italian food is typically called sweet basil, as opposed to Thai basil (O. basilicum var. thyrsiflora), lemon basil (O.X citriodorum) and holy basil (Ocimum tenuiflorum), which are used in Asia. While most common varieties of basil are treated as annuals, some are perennial in warm, tropical climates, including holy basil and a cultivar known as 'African Blue'. Physical properties of sweet basil which used in this study were determined, and presented in Table (1).

C. Meteorological measurements and Instrumentation: Solar radiation intensity $\left(\mathrm{I}, \mathrm{W} \cdot \mathrm{m}^{-2}\right)$, air temperature $\left(\mathrm{T},{ }^{\circ} \mathrm{C}\right)$, and relative humidity (Rh, $\%$ ) were measured daily from sunrise to sunset for the period of study.

1. Solar intensity measurement: The solar radiations flux incident on a horizontal and tilted surfaces were measured using a data acquisition system (TENMARS - Solar Power Meter - TM-206), with a measurement of 0.0 to $1999 \mathrm{~W} \cdot \mathrm{m}^{-2}$ and an accuracy of $0.1 \mathrm{~W} . \mathrm{m}^{-2}$ over a spectral range of 300 to $1100 \mathrm{~nm}$. Data were collected daily by a data logger at each $10 \mathrm{~min}$. and averaged over a time of $1 \mathrm{hr}$. interval.

Table (1): Physical properties of basil leaves.

\begin{tabular}{|c|c|c|c|}
\hline \multirow{2}{*}{ Properities } & \multicolumn{2}{|c|}{ Measured value } & \multirow{2}{*}{ Average } \\
\hline & maximum & minimum & \\
\hline Plant color & Light green & Light green & Light green \\
\hline Leaf type & silky leaves & silky leaves & silky leaves \\
\hline $\begin{array}{c}\text { Plant sensitivity } \\
\text { to weather } \\
\text { conditions }\end{array}$ & $\begin{array}{l}\text { Very sensitive } \\
\text { to cold }\end{array}$ & $\begin{array}{l}\text { Very sensitive } \\
\text { to cold }\end{array}$ & $\begin{array}{l}\text { Very sensitive } \\
\text { to cold }\end{array}$ \\
\hline Plant height, cm & 130 & 30 & 80 \\
\hline Leaflength, cm & 11 & 3 & 7 \\
\hline Leafbreadth, cm & 6 & 1 & 3.5 \\
\hline $\begin{array}{c}\text { Basil leaf } \\
\text { thickness, mm }\end{array}$ & 0.41 & 0.33 & 0.37 \\
\hline $\begin{array}{l}\text { Initial moisture } \\
\text { content of basil } \\
\text { leaves }(\% \text {, w.b) }\end{array}$ & 86.36 & 84.68 & 85.52 \\
\hline
\end{tabular}


2. Temperature and relative humidity measurements: Temperature and relative humidity inside and outside the solar drying unit were measured using a TENMARS-TM305-Temperature/Rh Data-logger (TENMARS ELECTRONICS CO., NEIHU, TAIWAN) and the specifications of this device are shown in Table (2). The air temperature and relative humidity were recorded daily for the period of study. Data were recorded at each $10 \mathrm{~min}$. by the data-logger and averaged over a time of $1 \mathrm{hr}$. interval. The temperature and relative humidity sensors were placed in multi-plate radiation shields above the ground by one meter to protect them from error-producing by solar radiation and precipitation.

Table (2): Specifications of temperature and humidity Data-logger.

\begin{tabular}{|c|cc|}
\hline \multirow{2}{*}{ Item } & \multicolumn{2}{|c|}{ Specifications } \\
\cline { 2 - 3 } & Temperature & Humidity \\
\hline $\begin{array}{c}\text { Measurement } \\
\text { Range }\end{array}$ & $40{ }^{\circ} \mathrm{C}$ to $85^{\circ} \mathrm{C}$ & $1 \%$ to $99 \%$ \\
\hline Accuracy & $\pm 0.6^{\circ} \mathrm{C}$ from- $20^{\circ} \mathrm{C}$ to $50^{\circ} \mathrm{C}$ & $\pm 3.0 \% \mathrm{RH}(20 \% \sim 80 \%)$ \\
Resolution & $\pm 1.0^{\circ} \mathrm{C}$ for all other ranges & $\pm 5.0 \% \mathrm{RH}(<20 \%,>80 \%)$ \\
\hline Type & $0.1^{\circ} \mathrm{C}$ & $0.1 \%$ \\
\hline
\end{tabular}

3. Airflow rate measurement: The airflow rate $\left(\mathrm{m}^{3} \cdot \mathrm{s}^{-1}\right)$ was measured using an orifice plates. The orifice plates were designed according to the International Standards Organization Standard No. ISO 5167-1980(E).

4. Moisture content measurement: An electric balance and electric oven were used for weighing and drying samples to determine the moisture content of both fresh and dried sweet basil leaves before and during the drying process. The capacity of the electric balance was $1 \mathrm{~kg}$ with accuracy of $\pm 0.01 \mathrm{~g}$. The samples were taken every two hour interval and dried on the electric oven at $105{ }^{\circ} \mathrm{C}$ for $24 \mathrm{hrs}$. The moisture content of sweet basil leaves was calculated on both wet and dry bases.

D. Chemical analysis: The chemical analysis was performed on both fresh and dried sweet basil leaves samples for the determination of the oil content $(\%)$ and chlorophyll content $(\mathrm{mg} / \mathrm{g})$. The essential oil was determined according to the method described in the British Pharmacopoeia (1963). Total chlorophyll contents were determined according to the method mentioned by Brougham (1960). 
E. Experimental Procedure: At the beginning of each experimental run, sweet basil leaves (Ocimum sanctum) were separated from basil plants and washed in tap water. Excess surface water from washed basil leaves was removed using blotting paper with slight pressing. Three different weights of each representative samples (clean leaves) were used to determine the average initial moisture content of basil leaves. The obtained results showed that the average initial moisture content of basil leaves was $85.52 \%$ w.b $(590.73 \%$ d.b), which were used for drying purpose on the same day. During the basil leaves drying process, both the drying units were operated simultaneously whereas during night (when the drying units were shut-off), both of the air inlet and outlet of each dryer unit were handily closed to maintained the drying chamber temperature at the desired temperature. For each drying run, the masses of labeled basil leaves samples were measured initially and every one hour intervals daily for determining the moisture content of basil leaves. The total and actual drying times, moisture removed from basil leaves were computed for each experimental run. The drying effectiveness (h/g moisture) is defined as the time required for removing $1 \mathrm{~g}$ moisture from the basil leaves during the experimental run. It was calculated by dividing the actual drying time by the amount of moisture removed from the basil leaves during the drying process. At the beginning of each drying run, the chemical analyses (oil content (\%) and chlorophyll content (mg/100g)) for fresh sweet basil leaves were determined. These chemical analyses for solar-dried basil leaves were determined at two airflow rates $\left(0.015 \mathrm{~m}^{3} / \mathrm{s}\right.$ and 0.025$)$ and three basil leaves depths (2, 4 and $6 \mathrm{~cm}$ ), while for sundried basil leaves (natural drying), the chemical analyses were determined at the same previous depths. The chlorophyll content $(\mathrm{mg} / \mathrm{g})$ was determined by using a spectronic 20D spectrophotometer (Brougham, 1960). The oil percentage (\%) was calculated (according to Guenther, 1975) using the following formula:

$$
X_{0}=\rho_{0} \times V_{0} \times 100 / W_{L}
$$

Where: $X_{o}$ is the percentage of the volatile oil, $(\%) ; \rho_{o}$ is the density of the volatile oil, $\left(\mathrm{g} \cdot \mathrm{cm}^{-3}\right) ; \mathrm{V}_{\mathrm{o}}$ is the volume of the volatile oil, $\left(\mathrm{cm}^{3}\right)$ and $\mathrm{W}_{\mathrm{L}}$ is the weight of sample, $(\mathrm{g})$. 


\section{F. Thermal Performance of Solar Collector:}

The thermal performance of the solar collector was estimated using the following equations:

1. Hourly average solar energy available on the collector surface $\left(\mathbf{q}_{\text {av }}\right)$ : The hourly average total solar radiation available on the specific tilted surface of the solar collector was calculated using the following formula:

$$
\mathbf{q}_{\mathrm{av}}=\mathbf{I}_{\mathbf{T}} \times \mathbf{A}_{\mathbf{C}}, \quad(\text { Watt })
$$

Where: $\mathrm{I}_{\mathrm{T}}$ is the solar radiation flux on the tilted solar collector, $\left(\mathrm{W} \cdot \mathrm{m}^{-2}\right)$.

$\mathrm{A}_{\mathrm{C}}$ is the surface area of the solar collector, $\quad\left(\mathrm{m}^{2}\right)$.

2. Useful heat energy gain $\left(\mathbf{Q}_{\mathbf{u s}}\right)$ : The useful heat energy gain is calculated as follows:

$$
Q_{u s}=m C p\left(T_{a o}-T_{a i}\right), \quad(W a t t)
$$

Where: $\mathrm{m}$ is the air mass flow rate, $\left(\mathrm{kg} . \mathrm{s}^{-1}\right) ; \mathrm{Cp}$ is the specific heat of air, $\left(\mathrm{J} \mathrm{kg}^{-1} .{ }^{\circ} \mathrm{C}^{-1}\right) ; \mathrm{T}_{\mathrm{ao}}$ and $\mathrm{T}_{\mathrm{ai}}$ are the outlet and inlet air temperatures of the solar collector, $\left({ }^{\circ} \mathrm{C}\right)$.

3. The thermal efficiency of the solar collector $\left(\boldsymbol{\eta}_{\text {th }}\right)$ : The thermal efficiency of the solar collector is calculated as follows:

$$
\eta_{\text {th }}=Q_{u s} / \mathbf{q}_{\mathrm{av}}=\left[\mathbf{m ~ C p}\left(\mathbf{T}_{\mathrm{ao}}-\mathbf{T}_{\mathrm{ai}}\right)\right] /\left(\mathbf{I}_{\mathrm{T}} \times \mathbf{A}_{\mathrm{C}}\right),(\%) \ldots(\mathbf{\%})
$$

\section{G. Calculations of the solar radiations:}

The estimated data was calculated by Excel-2003 Software. These calculations include:

- A technique of estimating the hourly average total solar radiation flux available on and gained on a south-facing solar collector using the meteorological and geographical parameters for Fayoum City (latitude and longitude angles are $29.18^{\circ} \mathrm{N}, 30.30^{\circ}$, respectively), Fayoum, Egypt on August.

- The procedure for obtaining the thermal efficiency of a solar collector for a flat-plate flow-over-absorber.

\section{RESULTS AND DISCUSSIONS}

Estimation of solar radiation and influences of some factors on the performance of the solar collector can be discussed as follows:

A. Solar radiation intensity and collector efficiency:

1. Hourly average incident solar radiation: The measured hourly average solar radiations incident on the horizontal plane and both of tilted 
surfaces, oriented at optimum angle $\left(15.7^{\circ}\right)$ and latitude angle $\left(30^{\circ}\right)$ for the month of August (2014) were hourly measured and the results were illustrated in Fig. (3). The results showed that, the hourly average solar radiations incident on the tilted surfaces of the solar collectors oriented at optimum and latitude angles almost clarified the same trend of that incident on the horizontal surface. The maximum values of hourly average solar radiations incident on the horizontal plane and tilted surface, oriented at optimum angle $\left(15.7^{\circ}\right)$ occurred at 12:00 noon, while the maximum values of the tilted surface oriented at latitude angle occurred at $2.00 \mathrm{pm}$. The daily average total solar radiations flux incidents on the tilted surfaces oriented at optimum angle $\left(15.7^{\circ}\right)$ and latitude angle $\left(30^{\circ}\right)$ were $29.30 \mathrm{MJ} \cdot \mathrm{m}^{-2} \cdot \mathrm{day}^{-1}$ and $24.62 \mathrm{MJ} \cdot \mathrm{m}^{-2} \cdot \mathrm{day}^{-1}$, respectively. Meanwhile, the daily average total solar radiation incident on the horizontal plane was $24.30 \mathrm{MJ} \cdot \mathrm{m}^{-2}$. $\mathrm{day}^{-1}$. Consequently, the tilted surface of the solar collector inclined with an optimum tilt angle $\left(15.7^{\circ}\right)$ for the month of August increased the solar energy by $20.58 \%$, because the optimum angle causes the beam radiation to be perpendicular on the collector surface during most of the day-time. On the other hand, the hourly average solar radiation incident on the horizontal plane was approximately equal to that incident on tilted surface oriented at latitude angle $\left(30^{\circ}\right)$. It was higher than that incident on tilted surface oriented at latitude angle $\left(30^{\circ}\right)$ before noon. Conversely, the hourly average solar radiation incident on tilted surface oriented at latitude angle $\left(30^{\circ}\right)$ was higher than that incident on the horizontal plane after noon until sunset.

\section{Hourly average useful energy gain and thermal efficiency of the} solar collectors: Because the higher values of the daily average solar radiations flux incident on the tilted surfaces oriented at the optimum angle $\left(15.7^{\circ}\right)$, which causes the beam radiation to be perpendicular on the collector surface during most of the day-time. Therefore, it was decided to calculate the average hourly useful energy gained and the thermal efficiency of both solar collectors tilted at the optimum tilt angle $\left(15.7^{\circ}\right)$ for the month of August at two different airflow rates (0.015 and 0.025 $\mathrm{m}^{3} \cdot \mathrm{s}^{-1}$ ) for Fayoum, Egypt (2014), and the results are shown in Table (3). 


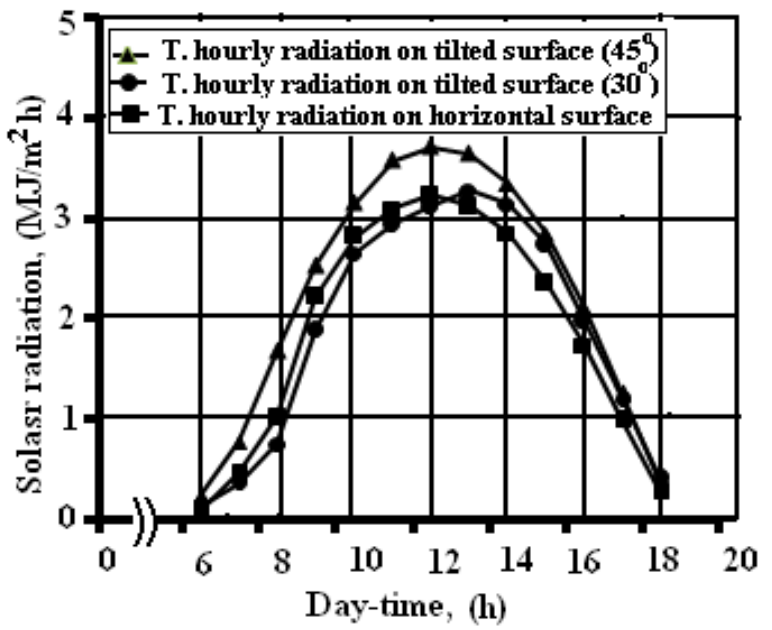

Fig. (3): Measured values of hourly average solar radiation incident on horizontal and tilted sufaces at latitude and optimum angles, for Fayoum, Egypt, in August.

The estimated values of the hourly average solar radiation incident on horizontal and tilted surfaces were measured, and used to calculate the solar energy gained and thermal efficiencies of the collectors. It s clear that, the hourly average overall thermal efficiency of the solar collector almost clarified the same trend of the useful energy gained, where the maximum value occurred at 12:00 noon. The results revealed that the hourly average overall thermal efficiency for the solar collector tilted at the optimum angle with the higher airflow rate was $43.11 \%$, which is relatively higher than that $(40.88 \%)$ with the lower airflow rate. Consequently, the solar collector with the higher airflow rate increased the hourly average overall thermal efficiency of the solar collector by $5.46 \%$ as compared with that of the lower airflow rate. Thus, for the purpose of solar drying, the maximum solar energy collection is desired for a given month to maximize the amount of solar energy gained by the solar drying unit and, consequently increasing its efficiency.

B. Inlet and outlet air temperatures of the solar collectors: The hourly average ambient temperature $\left(\mathrm{T}_{\mathrm{a}}\right)$ for Fayoum, Egypt and the outlet air temperature of the solar collector $\left(\mathrm{T}_{\mathrm{o}}\right)$ tilted at the optimum tilt angle $\left(15.7^{\circ}\right)$ was measured at two different airflow rates $\left(0.015 \mathrm{~m}^{3} \cdot \mathrm{sec}^{-1}\right.$ and $0.025 \mathrm{~m}^{3} . \mathrm{sec}^{-1}$ ) during the experimental period (August, 2014) and the results are graphically illustrated in Fig. (4). 
Table (3): Estimated values of hourly average solar radiation, gained energy and thermal efficiency of two solar collectors oriented at the optimum tilt angle $\left(15.7^{\circ}\right.$ ) for Fayoum, Egypt on August, 2014.

\begin{tabular}{|c|c|c|c|c|c|c|}
\hline \multirow{3}{*}{$\begin{array}{l}\text { Day- } \\
\text { time, } \\
\text { (h) }\end{array}$} & \multicolumn{2}{|c|}{$\begin{array}{c}\text { Solar radiation, } \\
\text { (MJ.rin lis) }\end{array}$} & \multicolumn{4}{|c|}{ Gained energy and efficiency of a solar collectors } \\
\hline & \multirow{2}{*}{$\mathrm{I}^{+}$} & \multirow{2}{*}{$\mathbf{I}_{\mathrm{T}}^{* *}$} & \multicolumn{2}{|c|}{ Gained energy,(Qis) } & \multicolumn{2}{|c|}{ Thermal efficiency, $\dot{\eta}(\%)$} \\
\hline & & & $(0.015)$ & $(0.025)$ & $(0.015)$ & $(0.025)$ \\
\hline 6 & 0.10 & 0.24 & 0.03 & 0.04 & 12.50 & 16.66 \\
\hline 7 & $\overline{0.46}$ & 0.78 & 0.18 & 0.21 & 23.08 & 26.92 \\
\hline 8 & 1.02 & 1.68 & 0.41 & 0.44 & 24.40 & 26.19 \\
\hline 9 & 2.22 & 2.53 & 0.78 & 0.82 & 30.83 & 32.41 \\
\hline 10 & 2.82 & 3.16 & 1.32 & 1.38 & 41.77 & 43.67 \\
\hline 11 & 3.10 & 3.58 & 1.64 & 1.72 & 45.81 & 48.05 \\
\hline 12 & 3.23 & 3.72 & 1.76 & 1.88 & 47.31 & 50.54 \\
\hline 13 & 3.12 & 3.65 & 1.69 & 1.72 & 46.30 & 47.12 \\
\hline 14 & 2.86 & 3.35 & 1.48 & 1.53 & 44.18 & 45.67 \\
\hline 15 & 2.36 & 2.86 & 1.22 & 1.27 & 42.66 & 44.41 \\
\hline 16 & 1.74 & 2.12 & 0.86 & 0.92 & 40.57 & 43.40 \\
\hline 17 & 0.99 & 1.26 & 0.47 & 0.49 & 37.30 & 38.89 \\
\hline 18 & 0.28 & 0.36 & 0.12 & 0.13 & 33.33 & 36.11 \\
\hline Sum. & 24.3 & 29.30 & 11.96 & 12.55 & - & - \\
\hline Average & 1.87 & 2.25 & 0.92 & 0.97 & 40.88 & 43.11 \\
\hline
\end{tabular}

* $\mathrm{I}=$ Hourly average radiation incident on the horizontal suface, $\left(\mathrm{MJ} . \mathrm{nit}^{-2} \mathrm{~h}_{\mathrm{h}}^{-1}\right)$ ** $\mathrm{J}_{\mathrm{T}}=$ Hourly average radiation incident on tilted suface, (MJ.2. $\mathrm{h}^{-1}$ )

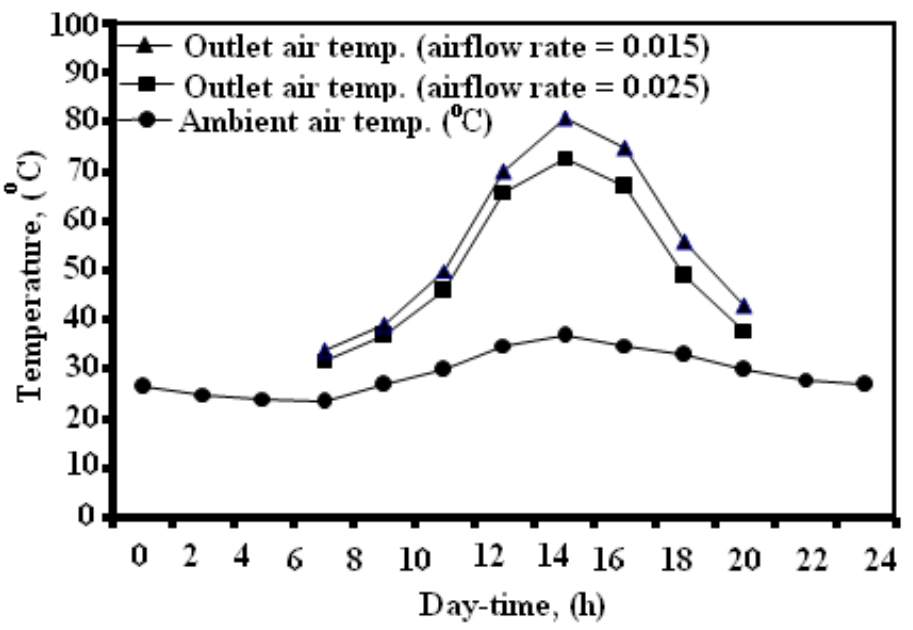

Fig. (4): Measured hourly average ambient and outlet temperatures of a solar collectors oriented at optimum tilt angle operated with two different aiflow rates for Fayoum, Egypt, in August, 2014. 
The results showed that, the outlet air temperature of the solar collector at two airflow rates were higher in most of the day-time (from 6:0 am to 8:0 pm) as compared with the corresponding values of the ambient temperature and almost take the same trend. The maximum values of the outlet temperatures for the solar collector with airflow rates of 0.025 and $0.015 \mathrm{~m}^{3}$. $^{\mathrm{sec}}{ }^{-1}$ were recorded to be $73.0{ }^{\circ} \mathrm{C}$ and $81.0{ }^{\circ} \mathrm{C}$, respectively, (at 2:0 $0 \mathrm{pm}$ ), whereas, the ambient air temperature reached to the maximum value of $37.0{ }^{\circ} \mathrm{C}$ (at 2:00 pm). The outlet air temperatures of the solar collector operated with airflow $0.015 \mathrm{~m}^{3} \cdot \mathrm{sec}^{-1}$ were higher as compared with the corresponding values of the outlet temperatures with airflow rate of $0.025 \mathrm{~m}^{3} . \mathrm{sec}^{-1}$. At August (2014), the diurnally temperature cycle ranged from $23.5{ }^{\circ} \mathrm{C}$ to $37.0{ }^{\circ} \mathrm{C}$ during the time of the day, while the two airflow rates provided two drying air temperature cycles (day-time) ranged from $32.0{ }^{\circ} \mathrm{C}$ to $73.0{ }^{\circ} \mathrm{C}$ and from 34.0 to $81.0{ }^{\circ} \mathrm{C}$ for the airflow rates of $0.025 \mathrm{~m}^{3} . \mathrm{sec} .1$ and $0.015 \mathrm{~m}^{3} . \mathrm{sec}^{-1}$, respectively. The results indicated that, the outlet temperature of the collector (drying air temperature) increased as the air flow rate decreased.

Two statistical equations were resulted from Excel-2003, which described the relationship between the outlet air temperatures from the solar collectors (at two airflow rates) and the hourly solar radiation incident on the horizontal plane $\left(\mathrm{MJ} \cdot \mathrm{m}^{-2} \cdot \mathrm{h}^{-1}\right)$. The following formulas are resulted:

$$
\begin{aligned}
& \mathrm{T}_{\text {out }(0.025)}=4.423(\mathrm{I})^{2}-5.245(\mathrm{I})+36.15 \\
& \mathrm{~T}_{\text {out }(0.015)}=\mathbf{4 . 2 8 3}(\mathrm{I})^{2}-\mathbf{5 . 3 3 5}(\mathrm{I})+\mathbf{3 4 . 2 7}
\end{aligned}
$$

Where: $\mathrm{T}_{\text {out (0.025) }}$ and $\mathrm{T}_{\text {out (0.015) }}$ are the outlet air temperatures from the solar collectors at air flow rates of 0.025 and $0.015 \mathrm{~m}^{3} \cdot \mathrm{sec}^{-1}$, respectively, and $\mathrm{I}$ is the hourly solar radiation incident on the horizontal plane (From 1.0 to $4.0 \mathrm{MJ} \cdot \mathrm{m}^{-2} \cdot \mathrm{h}^{-1}$ ).

C. Drying Rate of basil leaves: Generally, in the drying process, the rate of moisture loss is very important, since it affects the changes in the product properties. Therefore, effect of three basils leaves thicknesses (2, 4 and $6 \mathrm{~cm})$ and two airflow rates $\left(0.015\right.$ and $\left.0.025 \mathrm{~m}^{3} \cdot \mathrm{sec}^{-1}\right)$ were investigated, in order to evaluate their effects on the drying-rate of basil leaves.

1. Effect of basil leaves thickness on the drying rate: Fig. (5) shows the moisture content of basil leaves determined at two different airflow rates 
$\left(0.015\right.$ and $\left.0.025 \mathrm{~m}^{3} . \mathrm{sec}^{-1}\right)$ for three different basil leaves thicknesses $(2,4$ and $6 \mathrm{~cm}$ ). It is clear that, the 2-cm thick basil leaves layer dried fastest at both airflow rates, followed by the $4-\mathrm{cm}$ and the $6-\mathrm{cm}$ thick layers. The results indicated that, the finally average moisture contents (equilibrium) of basil leaves at all basil leaves thicknesses were found to be $11.52 \%$ (d.b.) and $14.58 \%$ (d.b.) at airflow rates of 0.015 and $0.025 \mathrm{~m}^{3} . \mathrm{sec}^{-1}$, respectively. This means that increasing the drying air temperature was sufficient to decrease the relative humidity and, thus, to increase the capacity of air to absorb moisture from the basil leaves, especially at the end stage of the drying process (when the moisture content of the basil leaves was low). At airflow rate of $0.015 \mathrm{~m}^{3} \cdot \mathrm{sec}^{-1}$ (drying air temperature cycle of $34.0-81.0{ }^{\circ} \mathrm{C}$ ), the moisture content of basil leaves reached its equilibrium after a total drying time of approximately 48, 69 and $121 \mathrm{~h}$ for the 2, 4 and $6 \mathrm{~cm}$ basil leaves thicknesses, respectively (Fig. 5-a), whereas at airflow rate of $0.025 \mathrm{~m}^{3} \cdot \mathrm{sec}^{-1}$ (drying air temperature cycle of 32.0 $73.0{ }^{\circ} \mathrm{C}$ ), the moisture content reached its equilibrium after a total drying time of approximately 45, 63 and $94 \mathrm{~h}$ for the 2, 4 and $6 \mathrm{~cm}$ for the same basil leaves thicknesses, respectively (Fig. 5-b).

2. Effect of airflow rate on the drying rate: Fig. (6) shows the moisture content of basil leaves determined at three basil leaves thick-layers (2, 4 and $6 \mathrm{~cm})$ for two different airflow rates $\left(0.015\right.$ and $\left.0.025 \mathrm{~m}^{3} . \mathrm{sec}^{-1}\right)$. At the $2 \mathrm{~cm}$ basil leaves thick-layer (Fig. 6-a), the moisture content reached its equilibrium after total drying time of approximately 48 and $45 \mathrm{~h}$ at the airflow rates of 0.015 and $0.025 \mathrm{~m}^{3} . \mathrm{sec}^{-1}$, respectively. At the $4 \mathrm{~cm}$ basil leaves thick-layer (Fig. 6-b), the moisture content reached its equilibrium after total drying time of approximately 69 and $673 \mathrm{~h}$ at the airflow rates of $0.015 \mathrm{~m}^{3} . \mathrm{sec}^{-1}$ and $0.025 \mathrm{~m}^{3} . \mathrm{sec}^{-1}$ respectively, whereas at $6 \mathrm{~cm}$ basil leaves thick-layers (Fig. 6-c), the moisture content reached its equilibrium after total drying time of approximately 121 and $94 \mathrm{~h}$ at airflow rate of $0.015 \mathrm{~m}^{3} . \mathrm{sec}^{-1}$ and $0.025 \mathrm{~m}^{3} . \mathrm{sec}^{-1}$ respectively. It is clear that, the lower moisture content was obtained at the higher airflow rate $\left(0.025 \mathrm{~m}^{3} / \mathrm{s}\right)$ as compared with the corresponding values, which obtained at the lower airflow rate $\left(0.015 \mathrm{~m}^{3} / \mathrm{s}\right)$ at all basil leaves thicknesses. This means that, increasing the airflow rate was sufficient to increase the capacity of air to absorb more moisture from the basil leaves. 


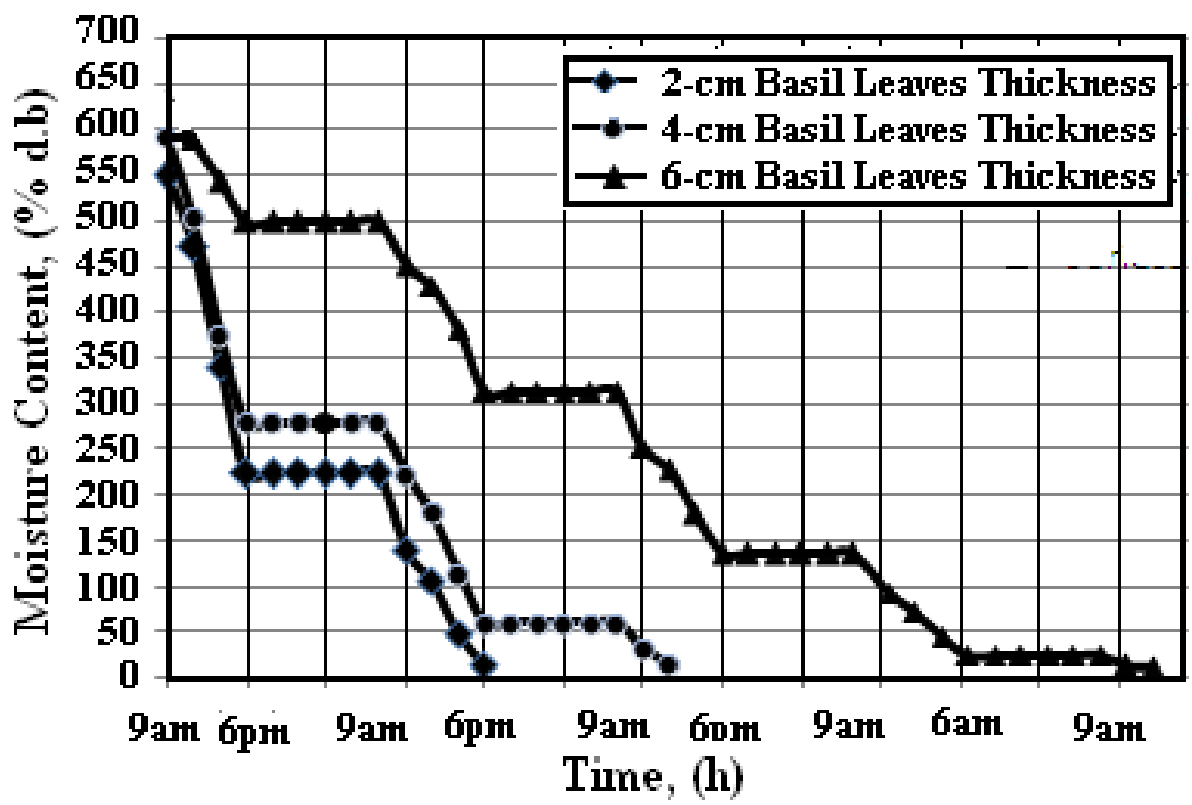

(a) Airflow Rate $=0.015 \mathrm{~m}^{3} / \mathrm{s}$

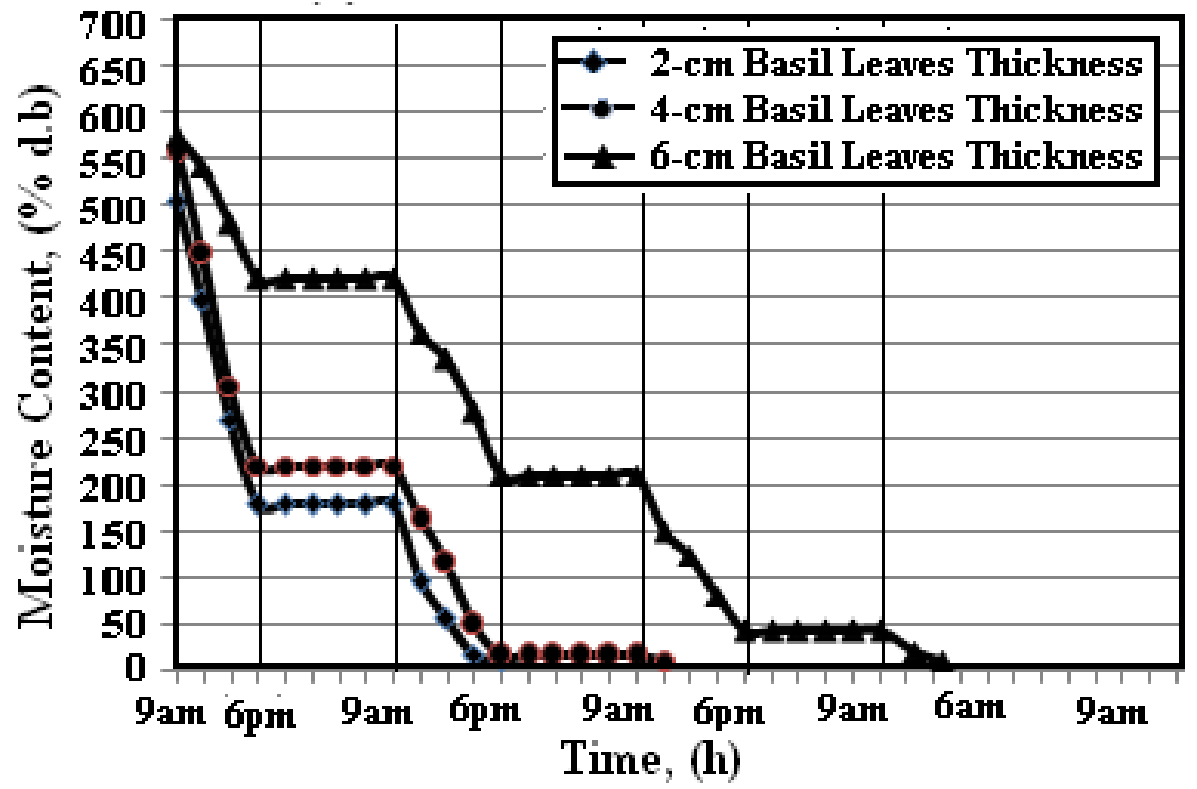

(b) Airflow Rate $=0.025 \mathrm{~m}^{3} / \mathrm{s}$

Fig. (5): Effect of basil leaves thickness on the moisture content of basil leaves at different ainflow rates 


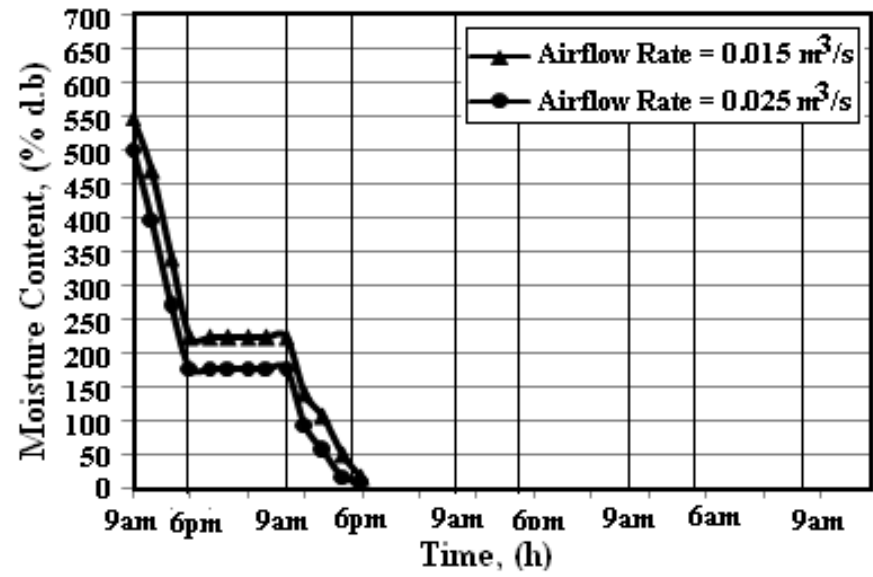

(a) Basil Leaves Thickness $=2 \mathrm{~cm}$

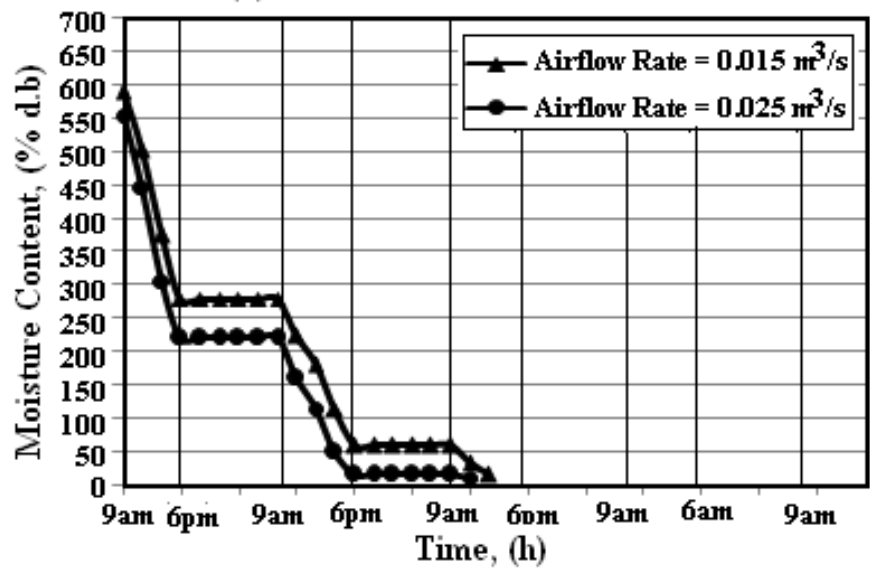

(b) Basil Leaves Thickness $=4 \mathrm{~cm}$

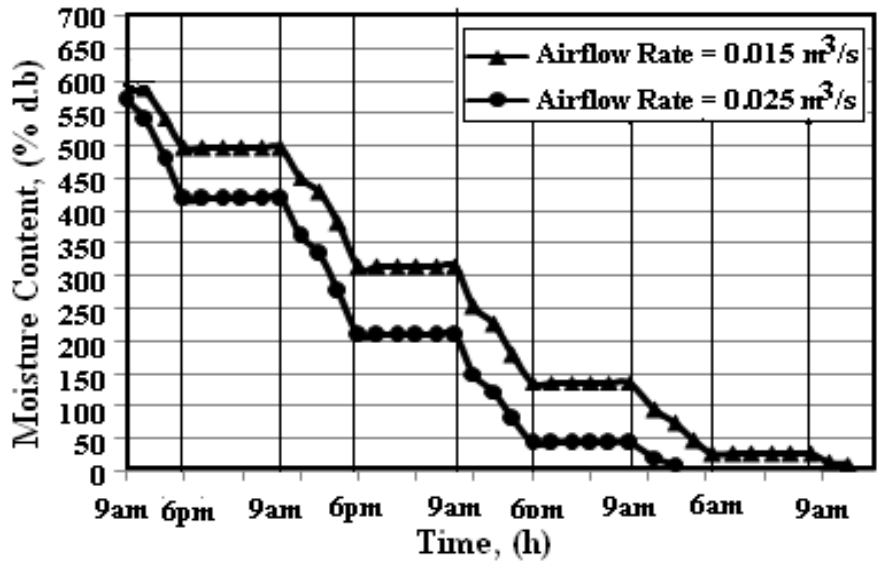

(c) Basil Leaves Thickness $=6 \mathrm{~cm}$

Fig. (6): Effect of airflow rate on the moisture content of basil leaves at different basil leaves thicknesses 
3. Drying effectiveness: The total and actual drying times, and the moisture removed from basil leaves during the drying processes were calculated to obtain the drying effectiveness (h. $\mathrm{g}^{-1}$ moisture) and the results are shown in Table (4). These calculations were made in order to compare the trends of the basil leaves drying effectiveness at various basil leaves thicknesses and airflow rates. It is clear that, the time required for driving off $1 \mathrm{~g}$ of moisture from the basil leaves decreased as both the airflow rate and basil leaves thickness increased. Thus, the least time required for drying basil leaves was for the $6-\mathrm{cm}$ thickness, followed by the 4-cm and 2-cm basil leaves thicknesses at both airflow rates. On the other hand, the time required to drive off $1 \mathrm{~g}$ of moisture from the basil leaves for the 2, 4 and $6 \mathrm{~cm}$-thick layers with the airflow rate of 0.015 $\mathrm{m}^{3} \cdot \mathrm{s}^{-1}$ were $0.341,0.241$ and $0.223 \mathrm{~h} . \mathrm{g}^{-1}$ moisture removed respectively, which was $3.96 \%, 7.1 \%$ and $3.72 \%$ higher than the corresponding values (0.328, 0.225 and .215 h. $\mathrm{g}^{-1}$ moisture removed) with the lower airflow rate $\left(0.025 \mathrm{~m}^{3} . \mathrm{s}^{-1}\right)$, respectively.

Table (4): Drying time and drying effectiveness of basil leaves at various ainflow rates and basil leaves thicknesses.

\begin{tabular}{|c|c|c|c|c|c|c|c|}
\hline \multirow{2}{*}{$\begin{array}{c}\text { Ainflow } \\
\text { rate } \\
\left(\mathbf{m}^{3} / \mathrm{s}\right)\end{array}$} & $\begin{array}{c}\text { Basil leaves } \\
\text { thickness } \\
(\mathrm{cm})\end{array}$ & \multicolumn{2}{|c|}{$\begin{array}{c}\text { Drying time } \\
\text { (h) }\end{array}$} & \multicolumn{2}{|c|}{$\begin{array}{c}\text { Basil leaves } \\
\text { weight }(\mathrm{g})\end{array}$} & $\begin{array}{c}\text { Moisture } \\
\text { removed } \\
(\mathbf{g})\end{array}$ & $\begin{array}{c}\text { Drying } \\
\text { Effectiveness } \\
\text { (h/g moisture })\end{array}$ \\
\cline { 3 - 6 } $0.015^{*}$ & 2 & 034 & 20 & 071.35 & 12.76 & 058.59 & 0.341 \\
& 4 & 069 & 24 & 128.13 & 28.46 & 099.67 & 0.241 \\
& 6 & 121 & 42 & 222.49 & 34.14 & 188.35 & 0.223 \\
\hline \multirow{3}{*}{0.025} & 2 & 32 & 18 & 062.96 & 08.12 & 054.84 & 0.328 \\
& 4 & 63 & 21 & 107.43 & 13.98 & 093.45 & 0.225 \\
& 6 & 94 & 34 & 176.30 & 18.24 & 158.06 & 0.215 \\
\hline
\end{tabular}

* Drying air temperature cycle $=34-81^{\circ} \mathrm{C}$

** Drying air temperature cycle $=32-73^{\circ} . \mathrm{C}$

The basil leaves thickness is one of the most important parameter affecting the basil leaves drying rate (g moisture removed /h). Fig. (7) shows the basil leaves drying rate at different basil leaves thicknesses with two airflow rates. It is clear that, the basil leaves drying rate increases as the basil leaves thickness increases and vice versa. Two equations were developed by the Excel-2003 soft-ware, and the following formulas are resulted: 


$$
\begin{aligned}
& D_{r(0.015)}=2.511 \mathrm{e}^{0.102(\mathrm{D})} \\
& \mathrm{D}_{\mathrm{r}(0.025)}=2.638 \mathrm{e}^{0.103(\mathrm{D})}
\end{aligned}
$$

Where: $\mathrm{D}_{\mathrm{r}(0.015)}$ and $\mathrm{D}_{\mathrm{r}(0.025)}$ are the drying rates ( $\mathrm{g}$ moisture removed. $\mathrm{hr}^{-1}$ ) with airflow rates of 0.015 and $0.025 \mathrm{~m}^{3} . \mathrm{sec}^{-1}$, and $\mathrm{D}$ is the basil leaves thickness $(\mathrm{cm})$.

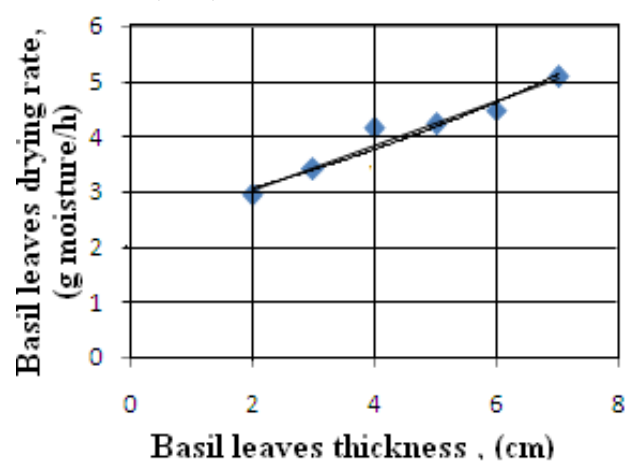

(a) Airflow rate $=0.015 \mathrm{~m}^{3} / \mathrm{s}$

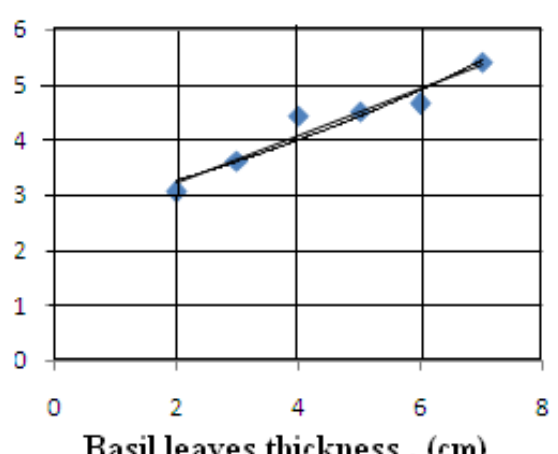

(b) Ainflow rate $=0.025 \mathrm{~m}^{3} / \mathrm{s}$

Fig. (7): Effect of basil leaves bthickness on the basil leaves drying rare with two different ainflow rates.

D. Effect of drying methods on quality of basil leaves: The solar drying method was found as more suitable for drying basil leaves, since the final dried product resembled the fresh basil leaves more closely in its chemical composition and had better appearance. The final dried product by the solar dryer (heated-air method) is better, clean and having a good quality as compared to that dried directly at the sun rays because it provides isolated atmosphere and suitable drying temperatures which minimize the contamination of the dried product. The solar dryer kept total chlorophyll contents of basil leaves higher than that dried directly at the sun while, on contrast, the essential oil contents of basil leaves were slightly higher for sun-dried as compared with that dried at the solar dryer (heated-air method).

F. Chemical analyses of sweet basil leaves: The chemical analyses for both fresh and dried basil leaves were determined and the results are listed in Table (5). The chemical analyses showed that the percentages of essential oil content and total chlorophyll contents in fresh-basil leaves were higher than that in both solar-dried and sun-dried basil leaves for the three different depths used. It's clear that, the percentages of essential oil 
content in solar-dried basil leaves at all depths increased when the air flow rate is increased, while on contrast, the total chlorophyll content in solar-dried basil leaves increased when the air flow rate is decreased. This due to the fact that increasing the airflow rate decreases the outlet temperature of the solar collector (inlet air to the drying chamber). On the other hand, the percentages of essential oil content for sun-dried basil leaves were slightly higher than that of solar-dried basil leaves at all depths, because the drying air temperatures for direct sun-drying were lower (ambient temperature). For the solar-dried basil leaves, the heated air drying method with air flow rate of $0.015 \mathrm{~m}^{3} . \mathrm{s}^{-1}$ and 2-cm basil leaves depth gave the highest essential oil contents, while the heated air drying method with air flow rate of $0.025 \mathrm{~m}^{3} . \mathrm{s}^{-1}$ and $4-\mathrm{cm}$ depth gave the highest values of total chlorophyll contents.

Table (5): Chemical analysis of sweet basil leaves as affected by the drying method.

\begin{tabular}{|c|c|c|c|c|}
\hline $\begin{array}{c}\text { Type of } \\
\text { basil leaves }\end{array}$ & $\begin{array}{c}\text { Air-flow rate } \\
\left(\mathbf{m}^{3} / \mathrm{s}\right)\end{array}$ & $\begin{array}{r}\text { Basil leaves } \\
\text { depth, }(\mathbf{c m})\end{array}$ & \begin{tabular}{|} 
Oil content, \\
$(\%)$
\end{tabular} & $\begin{array}{c}\text { Chlorophyll, } \\
(\mathbf{m g} / \mathbf{1 0 0 g})\end{array}$ \\
\hline \multirow{2}{*}{$\begin{array}{l}\text { Solar-dried } \\
\text { basil leaves }\end{array}$} & $0.015^{*}$ & $\begin{array}{l}2 \\
4 \\
6\end{array}$ & $\begin{array}{l}1.021 \\
1.072 \\
1.276\end{array}$ & $\begin{array}{l}72.512 \\
\mathbf{8 9 . 0 2 0} \\
65.977\end{array}$ \\
\hline & $0.025^{4 *}$ & $\begin{array}{l}2 \\
4 \\
6 \\
\end{array}$ & $\begin{array}{l}1.314 \\
1.289 \\
1.302 \\
\end{array}$ & $\begin{array}{l}57.222 \\
63.739 \\
48.462 \\
\end{array}$ \\
\hline \begin{tabular}{|l|} 
Sun-dried \\
basil leaves
\end{tabular} & $\begin{array}{l}\text { Natural } \\
\text { drying }\end{array}$ & $\begin{array}{l}2 \\
4 \\
6 \\
\end{array}$ & $\begin{array}{l}1.436 \\
1.302 \\
1.518 \\
\end{array}$ & $\begin{array}{l}49.332 \\
70.611 \\
54.049 \\
\end{array}$ \\
\hline \begin{tabular}{|c|} 
Fresh \\
basil leaves
\end{tabular} & - & - & 2.159 & 119.540 \\
\hline
\end{tabular}

Average of 3 replicates.

${ }^{*}$ At drying air temperature cycle $=32.0$ to $81.0^{\circ} \mathrm{C}$.

${ }^{*}$ At drying air temperature cycle $=30.0$ to $76.0^{\circ} \mathrm{C}$

\section{CONCLUSION}

The tilted surface of the solar collector inclined at the optimum tilt angle increased the solar radiation incident on the horizontal surface by $20.58 \%$. The higher airflow rate $\left(0.025 \mathrm{~m}^{3} \cdot \mathrm{s}^{-1}\right)$ increased the hourly average overall thermal efficiency of the solar collector by $5.46 \%$ as compared with the 
lower airflow rate $\left(0.015 \mathrm{~m}^{3} \cdot \mathrm{s}^{-1}\right)$. So that, the best results of basil leaves drying appeared with the higher air flow rate, this due to the high velocity of dry air with airflow rate of $0.025 \mathrm{~m}^{3} . \mathrm{s}^{-1}$ which, passed through the basil leaves compared with the low velocity of the lower airflow rate $(0.015$ $\left.\mathrm{m}^{3} \cdot \mathrm{s}^{-1}\right)$. The final moisture content of dried basil leaves ranged from ( $11.52 \%$ to $14.58 \%$ d.b) depending on the drying temperature cycle. Very small changes were observed in the colour and shape of heated-air dried basil leaves as compared to that dried at direct sun rays. The essential oil contents of dried basil leaves were slightly higher for the drying unit with the higher airflow rate as compared with the corresponding values obtained from the drying unit with the lower airflow at all basil leaves thicknesses. While on Contrast, total chlorophylls contents were slightly higher for the drying unit with the lower airflow rate as compared with the corresponding values obtained from the drying unit with the higher airflow at all basil leaves thicknesses. Under the conditions of this study, the optimum depth to dry basil leaves by using heated air is $4 \mathrm{~cm}$.

\section{REFERENCES}

Abdel-Galil, H. S. and Tarhuni, M. M. (2005). Solar Drying of Medicinal Plants under Libyan Conditions, Misr J. Agric. Eng., 22(4): 171-191.

Abdel-Galil, H. S. and El-Nakib, A. A. (2008). Effect of natural convection solar drying on quality of peppermint. The $15^{\text {th }}$ Conference of the Misr Society of Agric. Eng., 12-13 March 2008. Pp: $513-534$.

Arafa, G. K. (2007). Optimum drying conditions for thin-layer drying of sweet basil. Misr J. Ag. Eng., 24(3): 540- 556.

Banout, J; Havlik, J.; Kulik, M.; Kloucek, P.; Lojka B, and Valterov, I. (2010). Effect of solar drying on the composition of essential oil of sacha cilantro (Eryngium foetidum L.) grown in the peruvian amazon. J. Food Process Eng., 33: 83-103.

Baydar, H. and Erbas, S. (2009). Effects of harvest time and drying on essential oil properties in lavandin (lavandula $\times$ intermedia emeric ex loisel.). Acta Horticulturae, 826: 377-382. 
Bozin, B.; Mimica-Dukic, N.; Simin, N. and Anackov, G. (2006). Characterization of the volatile composition of essential oils of some lamiaceae spices and the antimicrobial and antioxidant activities of the entire oils. J. Agric. Food Chem. 54 (5): 18221828.

Brougham, R. W. (1960). The relationship between the critical leaf areas, total chlorophyll content and maximum growth rate of some pasture and crop plant Amm, 130t. N.S. 24(961): 463-474.

CAGMC, (Central Authority for General Mobilization and Statistics). (2003). "The Annual Stistical Book for A.R.E.:7".

Ertekin, C. and Yaldiz, O. (2004). Drying of eggplant and selection of a suitable thin layer drying models. J. Food Eng., 63: 349-359.

Hall, C. W. (1980). Drying and storage of agricultural crops. The AVI. Publishing, Inc., Westport, Connecticut, U.S.A.: 291-308.

Hassanain, A. A. (2004). Thermal Performance of an Unglazed Transpired Solar Dryer. Misr J. Agric. Eng. 12 (2):533-552.

Hazra, P., Kahol, A.P. and Ahmed, J. (1990). "Study of the effect of mode of drying on the yield, quality and steam consumption in distillation of the essential oil of Mentha arvesis". India-perfumer 34(1):47-55.

Kadam, D. M. ; Goyal, R. K. and Gupta, M. K. (2011). Mathematical modeling of convective thin layer drying of basil leaves. Journal of Medicinal Plants Research. 5(19):4721-4730.

Khangholil, S. and Rezaeinodehi, A. (2008). Effect of drying temperature on essential oil content and composition of sweet wormwood (Artemisia annua) growing wild in Iran. Pak.J. Biol. Sci, 11: 934-937.

Muhlbauer, W. (1986). Present Status of Solar Crop Drying. Energy in Agriculture 5, 121-137.

Okos, MR.; Narsimhan, G.; Singh, RK. and Weitnauer, AC. (1992). Food Dehydration. In: Heldman DR, Lund DB (Eds). Handbook of food engineering, New York; Marcel Dekker. 
Özcan, M.; Arslan, D. and Ünver, A. (2005). Effect of drying methods on the mineral content of basil (Ocimum basilicum L.). J. Food Eng., 69(3): 375-379.

Oztekin, S and Martinov, M. (2007). Medicinal and aromatic crops: Harvesting, drying and processing. Haworth food agricultural products press, New York, p. 320.

PaTil, B. G. and Ward, G. T. (1989). Simulation of Solar Air Drying of rapeseed. Solar Energy, 43(5):305-320.

Pierce, R. O. and Thompson, T. L. (1980). Management of solar and low temperature grain drying systems. Part II: Layer drying and solution to the over-drying problem. Transaction of the ASAE, 23(4):1020-1023.

Schenkel, E.P.; Gosmann, G. and Petrovick, P.R. (2003). Vegetable products and drug development. In: Simões, C.M.O et al. Pharmacognosy: Plant Med., eds. C. M. O. Editora da UFRGS/Editora UFSC, pp. 371- 400.

Sellami, I.H.; Wannes, W.A.; Bettaieb, I.; Berrima, S.; Chahed, T.; Marzouk, B. and Limam, F. (2011). Qualitative and quantitative changes in the essential oil of Laurus nobilis L. leaves as affected by different drying methods. Food Chem., 126: 691-697

Shahi, N. C.; Anupama Singh, and Kate, A. E. (2014). Activation energy kinetics in thin layer drying of basil leaves. International Journal of Science and Research (IJSR) ISSN (Online): 2319-7064. 3(7).

Tohti, I.; Tursun, M.; Umar, A.; Turdi, S.; Imin, H. and Moore, N. (2006). "Aqueous extracts of Ocimum basilicum L. (sweet basil) decrease platelet aggregation induced by ADP and thrombin in vitro and rat's arterio-venous shunt thrombosis in vivo". Thromb. Res. 118 (6): 733-739.

Yaldiz, O.; Ertekin, C. and Uzun, H.I. (2001). Mathematical modeling of thin layer solar drying of sultana grapes. Energy. Int. J. 26: 457465 . 


\section{الملخص العربى}

\section{تصميم وتثبيا وتقييم أداء وحدة تجفيف شمسي لأوراق الريحان}

أحمد طاهر إمبابى* حمدى سالم السيد عبدالجليل** طارق خميس عبدالقادر****

أجرى هذا البحث بهدف تصميم وتشسييد وتقييم أداء وحدة للتجفيف الثمسى بالهو اء المسخن، حيث تم تصميم هذه الوحدة وتنفيذها وتقييم أدائها فى كلية الزراعة - جامعة الفيوم - محافظة الفيوم، وقد أستخدمت هذه الوحدة لتجفيف أوراق الريحان الذى يعتبر من النباتات الطبية

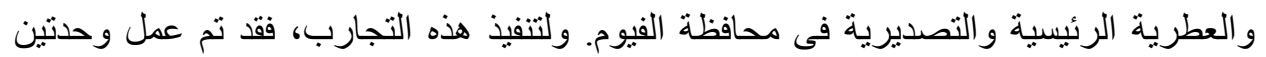
متماثلتين للتجفيف الثمسى، حيث تم تثبيتهما على السطح العلوى لمبنى قسم الأراضى و والمياه

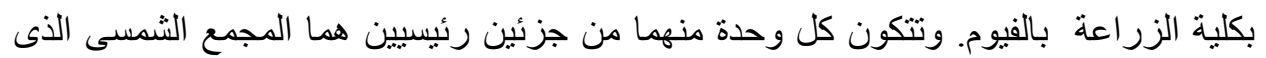

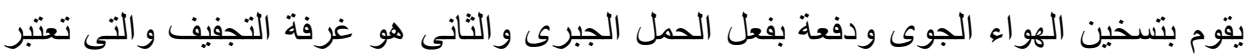

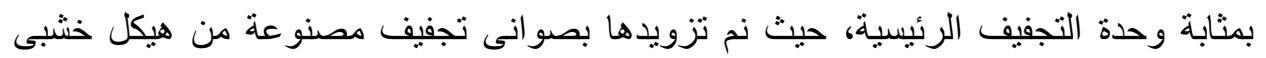

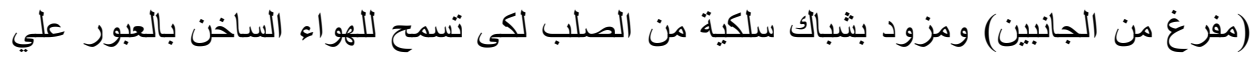

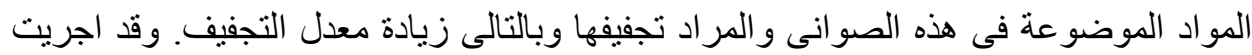

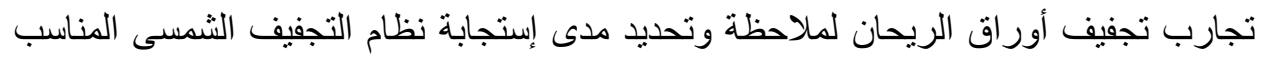

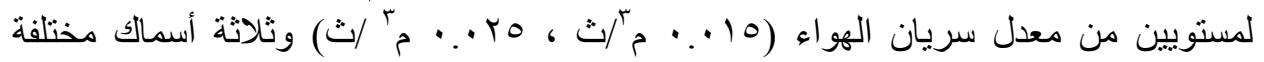

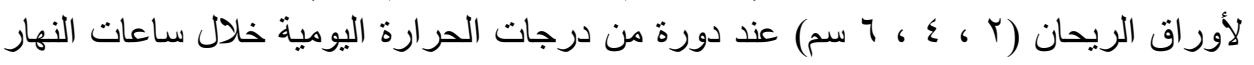

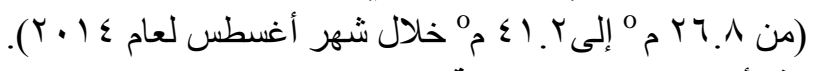

وقد أوضحت نتائج الار استة مايلى

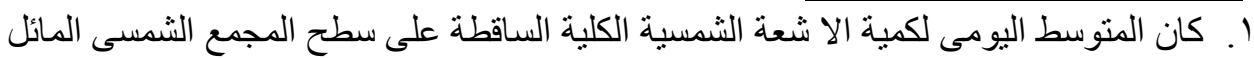

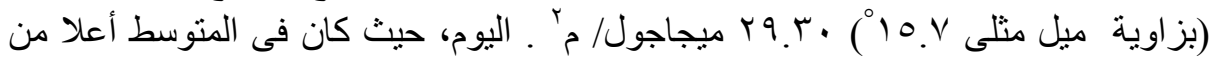

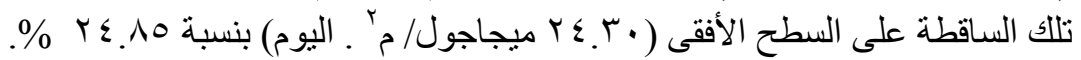

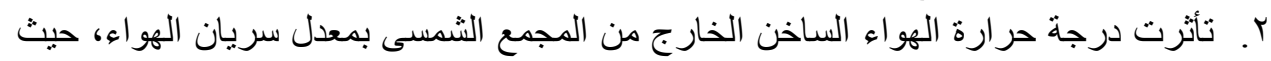

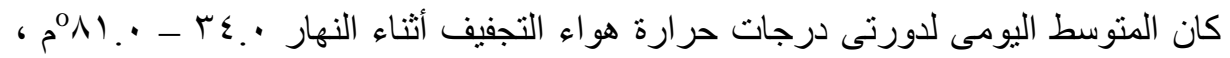

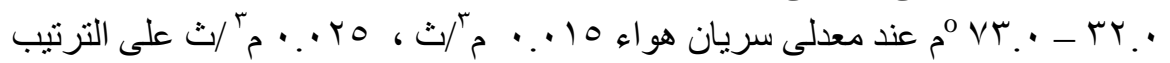

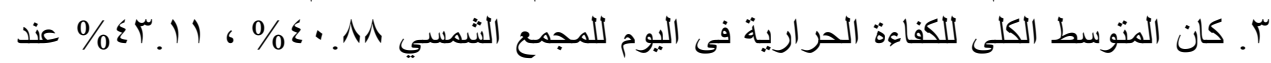

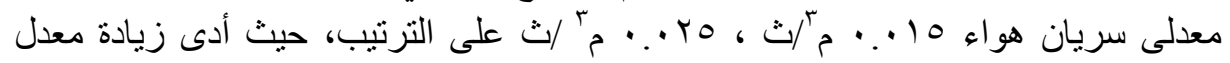

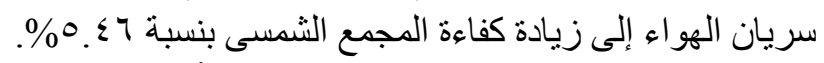

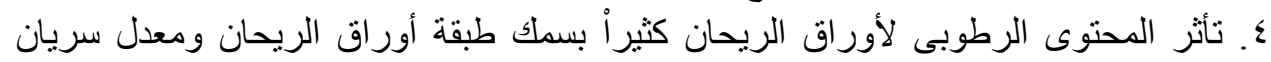

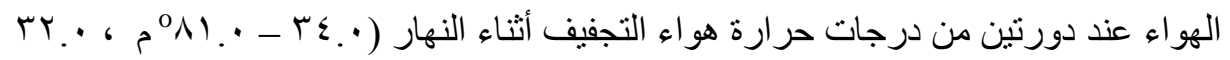

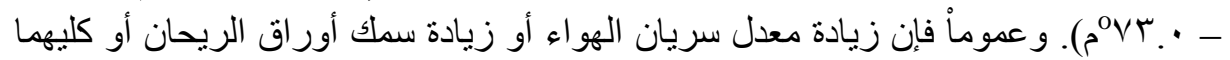

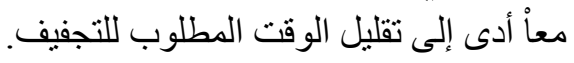

* ، * * أستاذ ، أستاذ مساعد ـ الهندسة الزراعية ـ كلية الزراعة ـ جامعة الفيوم.

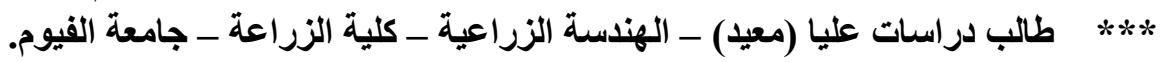




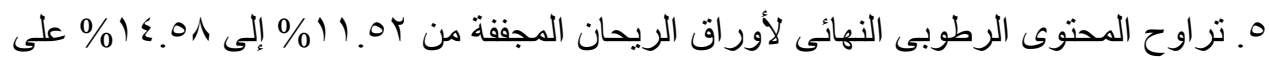

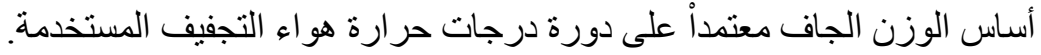

7. كانت أوراق الريحان المجفقة بالهواء الساخن فى المجفف الثمسى ذو جودة عالية، حيث

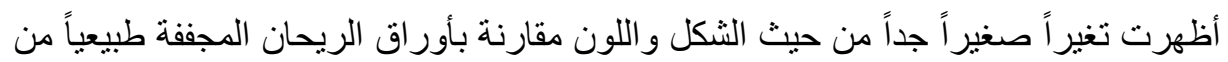
خلال التعريض لأشعة الثمس المباشرة جنرة

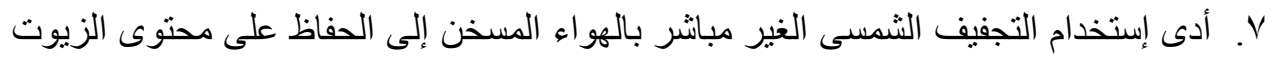

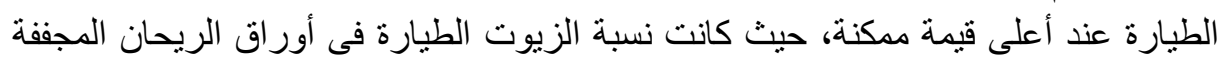

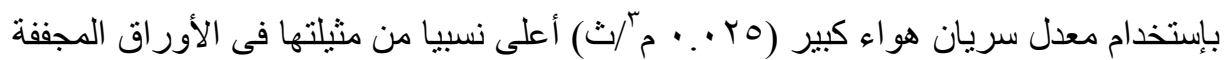

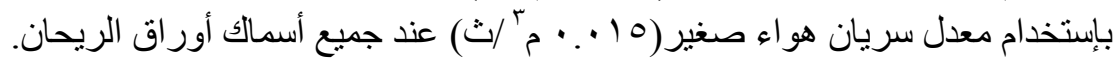

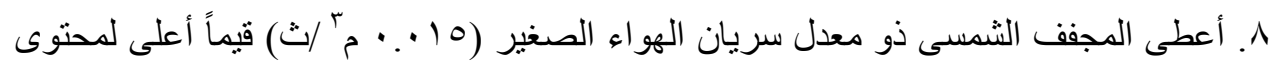

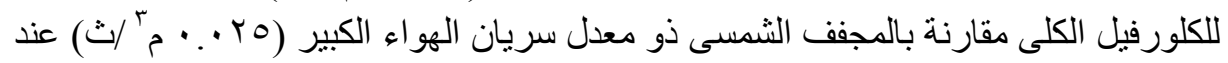
جميع أسماك أوراق الريحان.

9 ـ أستنبطت معادلتين احصائيتين للتنبؤ بقيمة درجات حرارة الهو اء الخارج من المجمع الثمسي قبل مرورة علي غرفة التجفيف، وكانت المعادلتين كالتالي :

$$
\begin{aligned}
& T_{\text {out }(0.025)}=4.423(I)^{2}-5.245(I)+36.15 \\
& T_{\text {out }(0.015)}=4.283(I)^{2}-5.335(I)+34.27
\end{aligned}
$$

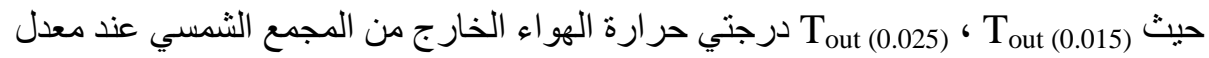

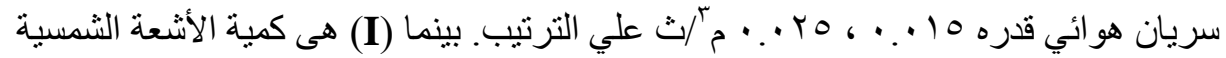

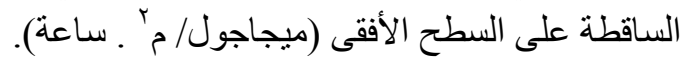

• . . أستنبطت معادلتين احصائيتين للتنبؤ بقيمة معدل تجفيف أور اق الريحان فى غرفة التجفيف عند

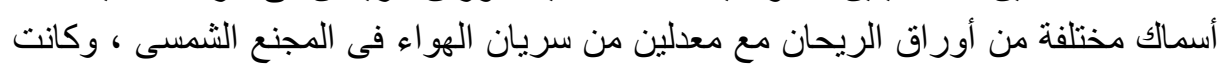
المعادلتين كالتالي:

$$
\begin{aligned}
& D_{r(0.015)}=2.511 \mathrm{e}^{0.102(\mathrm{D})} \\
& D_{r(0.025)}=2.638 \mathrm{e}^{0.103(\mathrm{D})}
\end{aligned}
$$

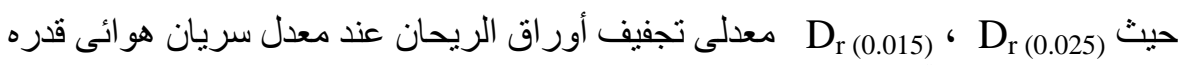
0 10

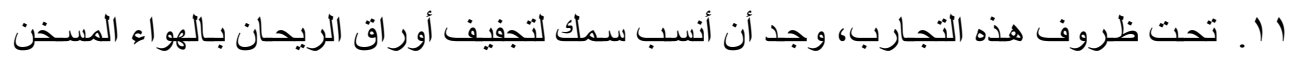

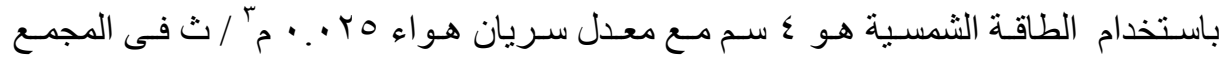
الشمسى. 